\title{
ARTICLE
}

\section{Carcinogenic and Non-carcinogenic Health Risk Assessment of Heavy Metals in Njaba River, Imo State, Nigeria}

\section{Victor Chukwuemeka Eze ${ }^{1 *}$ (iD, Chidiebere Temple Ndife $^{2}$, Miracle Oluebube Muogbo'}

${ }^{1}$ Department of Pure and Industrial Chemistry, Nnamdi Azikiwe University, P.M.B. 5025, Awka, Anambra State, Nigeria

${ }^{2}$ Department of Science Laboratory Technology, Federal Polytechnic Oko, Anambra State, Nigeria

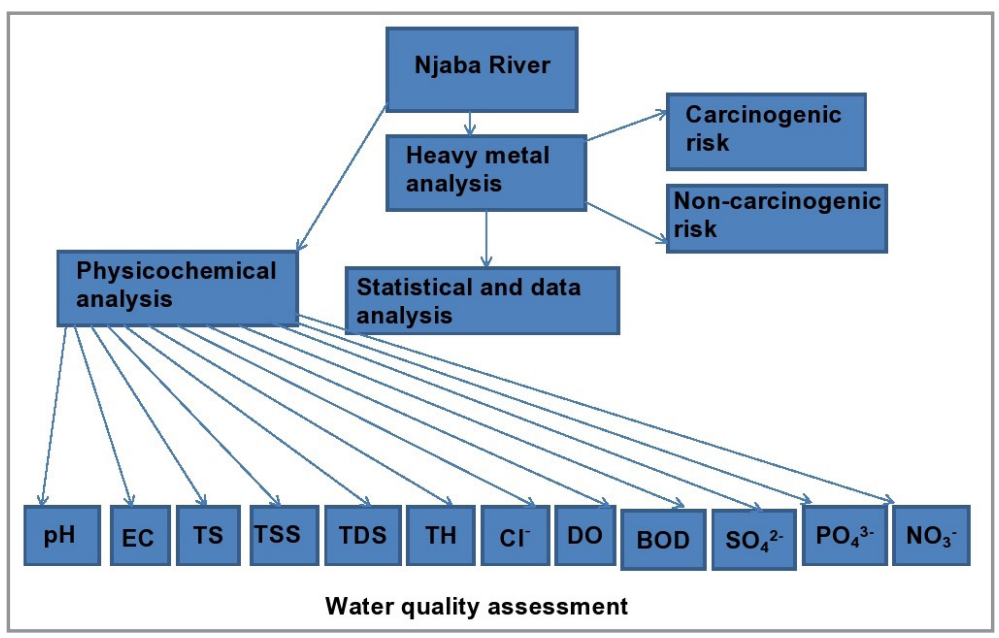
$\left(0.015 \pm 0.001\right.$ to $\left.0.021 \pm 0.001 \mathrm{mg} \mathrm{L}^{-1}\right), \mathrm{Cd}\left(0.006 \pm 0.002\right.$ to $\left.0.018 \pm 0.002 \mathrm{mg} \mathrm{L}^{-1}\right), \mathrm{Cr}(0.027 \pm 0.001$ to $\left.0.074 \pm 0.001 \mathrm{mg} \mathrm{L}^{-1}\right), \mathrm{Cu}\left(0.016 \pm 0.002\right.$ to $\left.0.033 \pm 0.001 \mathrm{mg} \mathrm{L}^{-1}\right)$, Ni $\left(0.031 \pm 0.001\right.$ to $\left.0.053 \pm 0.002 \mathrm{mg} \mathrm{L}^{-1}\right), \mathrm{Pb}$ $\left(0.050 \pm 0.002\right.$ to $\left.0.092 \pm 0.001 \mathrm{mg} \mathrm{L}^{-1}\right)$, and $\mathrm{Zn}\left(0.061 \pm 0.002\right.$ to $\left.0.097 \pm 0.002 \mathrm{mg} \mathrm{L}^{-1}\right)$. As, Ni and Pb recorded concentrations above their respective maximum permissible limits. Physicochemical parameters were appraised using the American Public Health Association standard method (APHA). The evaluation of the carcinogenic and non-carcinogenic health risks of the analyzed elements was carried out based on the guidelines of the USEPA. The hazard index values for children via upstream, midstream and downstream sample points were $0.0000128,0.00000895$ and 0.0513 respectively, while the hazard index values for adults via upstream, midstream and downstream sample points were $0.00000551,0.00000395$ and 0.00000581 respectively. The health risk estimation showed that the hazard quotients were within acceptable limits. The total cancer risks of potentially toxic elements were generally within the range of tolerable risk for adults and above the range of tolerable risk for children.

Keywords: Heavy metals, carcinogenic, hazard quotient, physicochemical, Njaba River.

Cite: Eze, V. C.; Ndife, C. T.; Muogbo, M. O. Carcinogenic and Non-carcinogenic Health Risk Assessment of Heavy Metals in Njaba River, Imo State, Nigeria. Braz. J. Anal. Chem., 2021, 8 (33), pp 57-70. doi: http://dx.doi.org/10.30744/brjac.2179-3425. AR-05-2021

Submitted 8 January 2021, Resubmitted 28 February 2021, Accepted 4 March 2021, Available online 26 March 2021. 


\section{INTRODUCTION}

Availability of uncontaminated water for human use has been a primordial and present issue in developing countries due to the associated health implications [1]. About $2 \%$ of the water resources on earth are from rivers, and only about $0.01 \%$ of the earth's water resource is fit for human consumption $[1,2]$. Surface waters such as rivers, streams, creeks, reservoirs, and lakes play an essential role in strengthening the economy of developing countries such as Nigeria [2-4]. Potentially toxic elements, organic and inorganic contaminants often contaminate rivers thereby making them unfit for domestic, agricultural and industrial purposes [3-5]. Due to the unique characteristics of potentially toxic elements (high toxicity at low concentrations, poor biodegradability and bioaccumulation), they pose a serious health threat to humans and aquatic life $[5,6]$. Similarly, the chronic low-level intake of water contaminated with potentially toxic elements such as chromium, cadmium, arsenic, and lead could seriously threaten human health [7-9]. Also, prolonged intake of potentially toxic elements can lead to accumulation in the kidneys, brain, bones, and livers in the human body $[6,7,10]$. In most cases, this often results in adverse health effects such as nervous system damage, poor growth and development, and even death, depending on the potentially toxic element and its chemical form $[6,10]$.

Over the years, the discharge of untreated wastewater from municipal, industrial, and agricultural activities into rivers, streams, and lakes have resulted in a high level of potentially toxic elements contamination in them $[7,8]$. Also, the levels and concentrations of potentially toxic elements in surface and ground waters vary significantly from one geographical area to another [10]. Akubugwo et al. [8] and Ahiarakwem \& Onyekuru [11] noted that the level of contamination of Njaba River in Imo State, Nigeria, is prominent. This is because Njaba River receives a large number of contaminants due to frequent rainfalls as well as the enormous superficial runoff due to precipitous water repositories which result in serious flooding within the area [13-15]. During flooding, potentially toxic elements in the soil dissolve in the floodwaters and are transported via seasonal floodplain surfaces into the river where they accumulate, and so, the river becomes enriched with the potentially toxic elements [15]. Numerous studies have revealed that contaminants tend to increase the potentially toxic element concentration in water bodies such as rivers $[8,11,12,15,16]$. To the best of our knowledge, studies focusing on non-carcinogenic and carcinogenic health risks of heavy metals in Njaba River, Imo State, are lacking and therefore, this study is aimed at filling the knowledge gap. Worthy of note is that potentially toxic elements enter the human body through several pathways, namely: dermal contact, oral ingestion, and inhalation, but in comparison to oral ingestion, all others are trivial [16-18].

In this research, the potential health risks due to exposure to potentially toxic elements were estimated in children and adults. Enyoh \& Isiuku [15] opined that health risk assessment is vital as it forms an integral part of safety management and occupational health.

Njaba River also provides water for agricultural purposes to the local population, which is more intense in the dry season. The river water is normally used without any prior assessment, even though many anthropogenic activities are carried out in and around the river [44]. Adults and children often consume water from recreational activities such as swimming in the river. The findings from this research will give an insight into the extent of contamination from potentially toxic elements in Njaba River, and also provide the necessary information that can help the decision-makers to establish comprehensive regulations and policies to protect the health of the populace within and around the area studied.

\section{MATERIALS AND METHODS Study area}

Njaba River is a major tributary of Oguta lake, located in the Niger Delta Basin, Imo State, Southeastern Nigeria. The river originated from Isu-Njaba, flows towards the south-west through Oguta lake and Njaba, passing through the southern parts of Ukworji, Umunnoha, and Oguta [8]. Njaba River lies within Latitudes $5^{\circ} 44^{\prime}$ and $5^{\circ} 47^{\prime}$ North $[8,11]$ and Longitudes $6^{\circ} 49^{\prime}$ and $7^{\circ} 03^{\prime}$ East $[8,11]$. The river has a total stream length of $78.2 \mathrm{~km}$, a mean depth of $4.5 \mathrm{~m}$, a basin area of $145.63 \mathrm{~km}^{2}$, and an average specific discharge of about 
$1700 \mathrm{~m}^{3} / \mathrm{h}[8,11,12]$. Geographically, the zone is divided by the lower Niger River into two unequal sections - an eastern section (which is the larger amongst the two) and a western section. Based on geology, the region is divided mainly into the Southeastern scarp lands under the Anambra/Imo river basin, and eastern borderlands under cross-river basins, and the apex of Udi Plateau at $300 \mathrm{~m}$ above sea level [43]. The river serves as a source of water for both domestic and agricultural purposes to the poor, and the entire local population. The pressure on the river increases during the dry season and festive periods due to a lack of alternative source of water supply [12]. The map of the study area and sample locations are depicted in Figure 1.

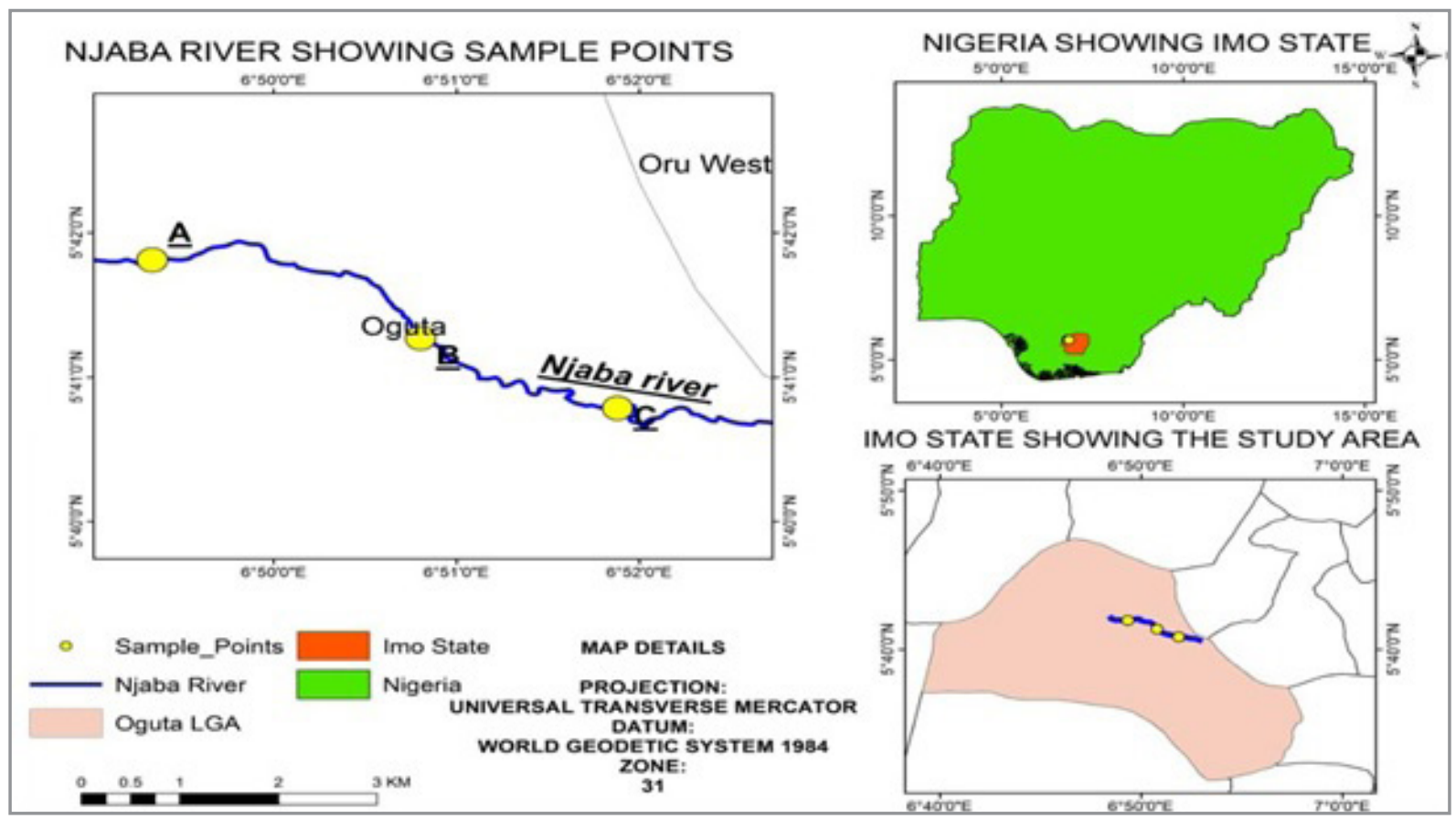

Figure 1. Map of Njaba River showing sample points.

\section{Collection of water samples}

The water samples for this study were collected from Njaba River at three sampling points. The sampling points are Upstream (A), Midstream (B) and Downstream (C). The sample points were at least $100 \mathrm{~m}$ apart. The water sampling was carried out according to the method prescribed by Akubugwo et al. [8]. Fifteen (15) water samples each were collected from the upstream, midstream and downstream. At each sample point, composite samples were collected and subsequently pooled together as one sample. The samples were kept at room temperature before they were taken to the laboratory for analysis. A total of 135 water samples were obtained for this study. Samples collection was done during the dry season between the months of January and March 2020.

\section{Concentration of potentially toxic elements in water samples}

The collected water samples were analyzed for potentially toxic elements using standard methods for the analysis of water samples as described by $[13,14]$. All chemicals used were analytical grade reagents with $>95 \%$ purity. De-ionized water was used during samples preparation and dilution of metal solutions. Agilent FS240AA atomic absorption spectrophotometer (AAS) was used to quantify the digested water samples for seven potentially toxic elements: arsenic (As), cadmium (Cd), chromium (Cr), copper (Cu), nickel $(\mathrm{Ni})$, lead $(\mathrm{Pb})$, and zinc $(\mathrm{Zn})$. Following the same protocol as the samples, standard reference material (SRM 2783) filter from the National Institute of Standards and Technology (NIST) was analyzed for 
potentially toxic elements concentration, and compared with their certified values to validate the analyses [18] and results obtained were reported to be within $\pm 5 \%$ of the certified values [18]. The limit of detection of the measured potentially toxic elements from the water samples are: As $=0.001 \mathrm{mg} \mathrm{L}^{-1}, \mathrm{Cd}=0.003 \mathrm{mg}$ $\mathrm{L}^{-1}, \mathrm{Cr}=0.001 \mathrm{mg} \mathrm{L}^{-1}, \mathrm{Cu}=0.0001 \mathrm{mg} \mathrm{L}^{-1}, \mathrm{Ni}=0.002 \mathrm{mg} \mathrm{L}^{-1}, \mathrm{~Pb}=0.001 \mathrm{mg} \mathrm{L}^{-1}, \mathrm{Zn}=0.0003 \mathrm{mg} \mathrm{L}^{-1}$.

\section{Statistical and data analysis}

Descriptive statistics (mean \pm standard deviation) was reported for the three sampling points (upstream, midstream and downstream). Significant differences were considered at $p<0.05$. The data obtained were compared with the recommended limits set by the Nigerian Standard for Drinking Water Quality (NSDWQ) [16] and World Health Organization (WHO) [28]. In this study, statistical analyses such as mean and standard deviation were carried out using IBM statistical package for social sciences version 20 (SPSS Inc., Chicago, IL, USA).

\section{Physicochemical parameter assessment}

The collected water samples were analyzed according to the method prescribed by the American Public Health Association [13]. The $\mathrm{pH}$ and electrical conductivity were measured in situ using $\mathrm{pH}$ meter and conductivity meter respectively [13]. Total solids (TS), total suspended solids (TSS), and total dissolved solid (TDS) were determined $[13,15]$. Total hardness (TH) was conducted by EDTA titrimetric method. Chloride $\left(\mathrm{Cl}^{-}\right)$was estimated using the Argentometric method [14]. Dissolved oxygen (DO) was determined using the modified Winkler's method according to [11,12]. Biochemical oxygen demand (BOD) was appraised using the method described by [16]. Sulphate $\left(\mathrm{SO}_{4}{ }^{2-}\right)$, phosphate $\left(\mathrm{PO}_{4}{ }^{3-}\right)$, and nitrate $\left(\mathrm{NO}_{3}{ }^{-}\right)$were estimated using the procedures given by [13].

\section{Human health risk assessment}

Health risk assessment involves estimating the probable occurrence and impact of a potentially harmful contaminant over a given period $[17,18]$. The potential health risk of each contaminant is usually based on the estimated risk level; and thus can be classified as non-carcinogenic or carcinogenic health risks $[18,19]$. In order to ascertain the degree of potentially toxic elements contamination, and possible health risks for children and adults, hazard quotients and incremental lifetime cancer risks were used. In this research, the priority groups were children and adults. The values used for calculating the chronic daily intake through oral ingestion are summarized in Table I.

Table I. Parameters and input assumptions for exposure assessment of potentially toxic elements for children and adults $[16,19]$

\begin{tabular}{llcccc}
\hline & & \multicolumn{3}{c}{ Values } \\
\cline { 3 - 5 } Parameter & Unit & \multicolumn{2}{c}{ Non-cancer } & \multicolumn{2}{c}{ Cancer } \\
\cline { 3 - 6 } & & Adult & Children & Adult & Children \\
\hline Heavy metal concentration $\left(\mathrm{C}_{\mathrm{w}}\right)$ & $\mu \mathrm{L}^{-1}$ & & & & \\
Daily average intake (DI) & L/day & 2.2 & 1.1 & 2.2 & 1.1 \\
Exposure frequency (EF) & Days/year & 365 & 365 & 365 & 365 \\
Exposure duration (ED) & Year & 70 & 6 & 70 & 6 \\
Bodyweight (BW) & Kg & 70 & 15 & 70 & 15 \\
ABS & All & 0.001 & 0.001 & 0.001 & 0.001 \\
Average time (AT) & Days & 25550 & 2190 & 25550 & 2190 \\
\hline
\end{tabular}


Non-carcinogenic health risk

Equation 1 obtained from $[21,44]$ was applied to determine the chronic daily intake of potentially toxic elements for children and adults via ingestion exposure routes [16,19-21].

$$
C D I_{\text {ingestion }}=C_{W} \times D I \times A B S \times E F \times E D / B W \times A T
$$

where, $C_{w}$ (in $\mu \mathrm{g} \mathrm{L}^{-1}$ ) is the heavy metals concentration in water, $A B S$ (no unit) is the dermal absorption factor, $D I$ (in L/day) is the daily average intake of water in the area, $E F$ (in days/ year) represents the annual exposure frequency, $E D$ (in years) is exposure duration, $B W$ (in $\mathrm{kg} / \mathrm{person}$ ) is bodyweight, and $A T$ (in days) is the average time $[16,19-21,44]$.

The $H Q$ for individual potentially toxic elements was estimated using the ratio of the calculated mean daily intake (CDI, mg L-1/day) of the metal ingested through contaminated water to the reference dose (RfD). Sum of all the hazard quotients give the total potential health risks or hazard index $(H I)[16,19]$. The calculation of the $H Q$ caused by water is presented in Equation 2.

$$
H Q=C D I / R f D
$$

where $C D I$ and $R f D$ are expressed in $\mathrm{mg} \mathrm{L}^{-1} /$ day. The values of the RfD and cancer slope factor for different metals studied are listed in Table II.

\section{Hazard Index (HI)}

In order to evaluate the entire non-carcinogenic health impacts caused by exposure to a mixture of potentially toxic elements in River Njaba, the $\mathrm{HI}$ for seven potentially toxic elements was computed according to the USEPA guidelines for health risk assessment $[16,18,19,21]$ using Equation 3.

$$
H I=H Q_{A s}+H Q_{C d}+H Q_{C r}+H Q_{C u}+H Q_{N i}+H Q_{P b}+H Q_{Z n}
$$

The computed $\mathrm{HI}$ is compared to standard values: there is the possibility that non-carcinogenic impacts may occur in the residents when $H I>1$, while the exposed person is unlikely to experience evident harmful health impacts when $H I<1[16,18,24,25]$.

Table II. Reference dose (RfD) and cancer slope factor (CSF) for different potentially toxic elements $[16,21,24]$

\begin{tabular}{lcc}
\hline Potentially toxic elements & RfD $_{\text {oral ingestion }}$ & CSF (mg L-1/day) \\
\hline $\mathrm{As}$ & 0.30 & 1.50 \\
$\mathrm{Cd}$ & 0.50 & 6.10 \\
$\mathrm{Cr}$ & 3.00 & 41.00 \\
$\mathrm{Cu}$ & 40.00 & $\mathrm{NAD}$ \\
$\mathrm{Ni}$ & 20.00 & 0.84 \\
$\mathrm{~Pb}$ & 1.40 & 8.50 \\
$\mathrm{Zn}$ & 300.00 & $\mathrm{NAD}$ \\
\hline
\end{tabular}

$\mathrm{NAD}=$ No Available Data 


\section{Carcinogenic health risk}

This is usually estimated using the Incremental Lifetime Cancer Risk (ILCR) $[16,24,26]$. The ILCR is the possibility of a person developing any type of cancer over a lifetime as a result of daily exposure to a given daily amount of a carcinogenic element $[16,19,21,26]$. Equation 4 was used for the calculation of the lifetime cancer risk.

$$
I L C R=C D I \times C S F
$$

where CSF is the cancer slope factor. The allowable limits are considered to be $10^{-6}$, and less than $10^{-4}$ for both single and multi-element carcinogens $[16,26,27]$.

\section{RESULTS AND DISCUSSIONS Concentrations of potentially toxic elements}

The concentrations of potentially toxic elements (Table III) in Njaba River revealed the presence of arsenic $\left(0.015 \pm 0.001\right.$ to $\left.0.021 \pm 0.001 \mathrm{mg} \mathrm{L}^{-1}\right)$, cadmium $\left(0.006 \pm 0.002\right.$ to $\left.0.018 \pm 0.002 \mathrm{mg} \mathrm{L}^{-1}\right)$, chromium $\left(0.027 \pm 0.001\right.$ to $\left.0.074 \pm 0.001 \mathrm{mg} \mathrm{L}^{-1}\right)$, copper $\left(0.016 \pm 0.002\right.$ to $\left.0.033 \pm 0.001 \mathrm{mg} \mathrm{L}^{-1}\right)$, nickel $(0.031 \pm 0.001$ to $\left.0.053 \pm 0.002 \mathrm{mg} \mathrm{L}^{-1}\right)$, lead $\left(0.050 \pm 0.002\right.$ to $\left.0.092 \pm 0.001 \mathrm{mg} \mathrm{L}^{-1}\right)$ and zinc $(0.061 \pm 0.002$ to $0.097 \pm 0.002$ $\left.\mathrm{mg} \mathrm{L}^{-1}\right)$. Arsenic, nickel, and lead recorded concentrations higher than their respective NSDWQ and WHO [28] maximum permissible limits. The concentrations recorded for cadmium and chromium in midstream were lower than their respective NSDWQ and WHO [28] maximum permissible limits. Also, Cu and Zn concentrations were lower than their respective NSDWQ and WHO [28] maximum permissible limits. These results were slightly in contrast to the data reported by Akubugwo et al. [8] where the authors reported low levels in both upstream and downstream of the river. However, Ahiarakwem et al. [45] reported a high concentration for $\mathrm{Cr}, \mathrm{Cd}, \mathrm{Ni}, \mathrm{Zn}$, and Fe which was attributed to anthropogenic activities around the river. High concentrations of some potentially toxic elements reported in this study are undesirable. Potentially toxic elements such as arsenic cause skin infections, vascular diseases and visceral cancers; cadmium is a human carcinogen that causes renal disorder, and damage of the kidney; chromium causes nausea and vomiting, diarrhea, headache; copper has been associated with Wilson disease, gastrointestinal irritation, insomnia (sleeplessness), and liver damage; nickel, a human carcinogen causes nausea, dermatitis, chronic asthma, and coughing; lead causes damage to the circulatory and nervous system, fetal brain, and diseases of the kidney; zinc causes lethargy, neurological signs, depression, and increased thirst [8,16,29-31]. Generally, human activities such as oil spills from automobiles, bathing, washing vehicles and clothes, causes increased levels of potentially toxic elements in water bodies such as streams, lakes, and rivers [18]. All studied metals showed significant differences $(p<0.05)$ in the different sample points of the river. There were no definite trends for the studied potentially toxic elements; some potentially toxic elements ( $\mathrm{Cd}, \mathrm{Cr}, \mathrm{Cu}, \mathrm{Ni}$ and $\mathrm{Zn}$ ) showed the highest concentration upstream while some (As and $\mathrm{Pb}$ ) had the highest concentration downstream of the river. 
Table III. Potentially toxic elements concentration levels in Njaba River

\begin{tabular}{lccccc}
\hline $\begin{array}{l}\text { Potentially toxic } \\
\text { elements }\end{array}$ & $\begin{array}{c}\text { Upstream } \\
\left(\mathrm{mg} \mathrm{L}^{-1}\right)\end{array}$ & $\begin{array}{c}\text { Midstream } \\
\left(\mathrm{mg} \mathrm{L}^{-1}\right)\end{array}$ & $\begin{array}{c}\text { Downstream } \\
\left(\mathrm{mg} \mathrm{L}^{-1}\right)\end{array}$ & $\begin{array}{c}\text { NSDWQ } \\
\text { Standards } \\
(\mathrm{MPL})^{*}[16]\end{array}$ & $\begin{array}{c}\text { WHO* Standard } \\
{[29]}\end{array}$ \\
\hline $\mathrm{As}$ & $0.015 \pm 0.001^{\mathrm{a}}$ & $0.019 \pm 0.002^{\mathrm{ab}}$ & $0.021 \pm 0.001^{\mathrm{b}}$ & 0.01 & 0.01 \\
$\mathrm{Cd}$ & $0.018 \pm 0.002^{\mathrm{a}}$ & $0.006 \pm 0.001^{\mathrm{c}}$ & $0.012 \pm 0.002^{\mathrm{c}}$ & 0.03 & 0.01 \\
$\mathrm{Cr}$ & $0.074 \pm 0.001^{\mathrm{b}}$ & $0.027 \pm 0.001^{\mathrm{a}}$ & $0.050 \pm 0.001^{\mathrm{c}}$ & 0.05 & 0.05 \\
$\mathrm{Cu}$ & $0.033 \pm 0.001^{\mathrm{a}}$ & $0.016 \pm 0.002^{\mathrm{b}}$ & $0.025 \pm 0.001^{\mathrm{c}}$ & 1.00 & 2.00 \\
$\mathrm{Ni}$ & $0.053 \pm 0.002^{\mathrm{a}}$ & $0.031 \pm 0.001^{\mathrm{c}}$ & $0.044 \pm 0.002^{\mathrm{b}}$ & $\mathrm{NHB}^{*}$ & 0.02 \\
$\mathrm{~Pb}$ & $0.085 \pm 0.001^{\mathrm{a}}$ & $0.050 \pm 0.002^{\mathrm{c}}$ & $0.092 \pm 0.001^{\mathrm{b}}$ & 0.01 & 0.01 \\
$\mathrm{Zn}$ & $0.097 \pm 0.002^{\mathrm{a}}$ & $0.061 \pm 0.002^{\mathrm{b}}$ & $0.077 \pm 0.001^{\mathrm{ab}}$ & 3.00 & 5.00 \\
\hline
\end{tabular}

The results are means and standard deviations of triplicate determinations. Values with similar alphabets along the same row are not statistically significant at $p<0.05$. Values with different alphabets along the same row are statistically significant at $p<0.05$.

${ }^{*}$ NSDWQ (MPL): Nigerian Standard for Drinking Water Quality; MPL: Maximum Permissible Limits; WHO: World Health Organization; NHB= No Health Baseline.

\section{Physicochemical analysis}

The mean concentrations of the physicochemical parameters assessed in Njaba River are represented in Table IV. The physicochemical properties showed significant differences at different points except for some parameters such as BOD, sulphate and phosphate which showed significant differences between downstream and upstream and midstream. From the table, $\mathrm{pH}$ values of the sampling points ranged from $5.95 \pm 0.23$ to $6.43 \pm 0.11$ and were lower than NSDWQ and WHO [28] maximum permissible limits. Similar $\mathrm{pH}$ has been reported previously by $[8,45,46]$ for rivers in Imo state. The $\mathrm{pH}$ of the studied water body is acidic. The low pH of water bodies could be attributed to the presence of humic acids generated from decaying aquatic plants and animals [32]. Akubugwo et al. [8] noted that daily ingestion of water with low $\mathrm{pH}$ could lead to peptic ulcer. Electrical conductivity values recorded in the studied river ranged from $2847 \pm 11.11$ to $6838 \pm 9.98 \mu \mathrm{S} \mathrm{cm}^{-1}$. The conductivity values were higher than NSDWQ [16] maximum permissible limit and also higher than the reported values for river Uramiriuka in Owerri, Imo state [46]. A strong relationship between total dissolved solid and electrical conductivity in water has been reported by [33]. Total solid, total suspended solid, and total dissolved solid values ranged from $3050 \pm 3.04$ to $7800 \pm 1.98,1000 \pm 1.03$ to $2500 \pm 0.99$, and $2500 \pm 0.5$ to $5800 \pm 0.53 \mathrm{mg} \mathrm{L}^{-1}$ respectively. These reported values are higher than NSDWQ [16] and WHO [28] maximum permissible limit. The reported high values are a clear indication of anthropogenic activities on the studied river. Worthy of note is that people use water from the river for agricultural, industrial, and domestic purposes. Consumption of water with high total solid, total suspended solid, and total dissolved solid are harmful to the body system of humans [8]. The values recorded for total hardness ranged from $55.00 \pm 0.77$ to $95.50 \pm 0.35 \mathrm{mg} \mathrm{L}^{-1}$. These values are lower than the NSDWQ and WHO [28] maximum permissible limits. This implies that Njaba River is moderately soft. Gray [34] stated that water could be classified as soft water when the degree of hardness is $0-50 \mathrm{mg} \mathrm{L}^{-1}$. Also, soft water is known to form lather readily with soap. Chloride ranged from $72 \pm 0.08$ to $85 \pm 0.19 \mathrm{mg} \mathrm{L}^{-1}$. The values reported for chloride were lower than the NSDWQ and WHO [28] maximum permissible limits. However, the presence of chloride in Njaba River is a sign of pollution due to human activities. Dissolved oxygen (DO) and biological oxygen demand (BOD) values ranged from 2.05 \pm 0.59 to $3.18 \pm 0.65 \mathrm{mg} \mathrm{L}^{-1}$ and $5.55 \pm 0.66$ to $6.00 \pm 0.60 \mathrm{mg} \mathrm{L}^{-1}$ respectively. The DO and BOD values of Njaba River as revealed in this research are lower than the WHO [28] maximum permissible limit. Garg et al. [35] 
noted that dissolved oxygen concentration greater than $5.00 \mathrm{mg} \mathrm{L}^{-1}$ supports aquatic life. DO and BOD are essential for the self-purification process in water bodies [36]. Sulphate, phosphate and nitrate values in Njaba River ranged from $15.76 \pm 3.33$ to $16.23 \pm 2.09,47.45 \pm 1.03$ to $49.55 \pm 0.97$ and $0.81 \pm 0.13$ to $0.99 \pm 0.06$ $\mathrm{mg} \mathrm{L}^{-1}$ respectively. The phosphate levels in this research were higher than the WHO [28] maximum permissible limit while the sulphate and nitrate levels were lower than the NSDWQ [16] and WHO [28] maximum permissible limits respectively. The results reported in this study are in contrast to reports of [43], in which lower concentrations were obtained for nitrate and phosphate. High phosphate in the river was recorded due to the continuous use of phosphate-based fertilizers on the surrounding farmlands. High phosphate contents in rivers lead to the existence of blue-green algae on the surfaces [12]. Furthermore, the low sulphate and nitrate concentrations recorded in the river implies that there is a low possibility of the development of methaemoglobinaemia in children (infants) $[8,12,37,43]$.

Table IV. Physicochemical parameters of Njaba River

\begin{tabular}{|c|c|c|c|c|c|}
\hline Parameters & Upstream & Midstream & Downstream & $\begin{array}{c}\text { NSDWQ } \\
\text { Standards* } \\
{[16]}\end{array}$ & $\begin{array}{c}\text { WHO* } \\
\text { Standard } \\
\text { [28] }\end{array}$ \\
\hline $\mathrm{pH}$ & $5.95 \pm 0.23^{a}$ & $6.43 \pm 0.11^{\mathrm{a}}$ & $6.21 \pm 0.34^{\mathrm{a}}$ & $6.5-8.5$ & $6.5-8.5$ \\
\hline $\begin{array}{l}\text { Electrical conductivity } \\
\left(\mu \mathrm{cm}^{-1}\right)\end{array}$ & $2847 \pm 11.11^{\mathrm{a}}$ & $5236 \pm 6.05^{b}$ & $6838 \pm 9.98^{c}$ & 1000 & $\mathrm{NHB}$ \\
\hline Total solids $\left(\mathrm{mg} \mathrm{L}^{-1}\right)$ & $3050 \pm 3.04^{a}$ & $5500 \pm 1.01^{b}$ & $7800 \pm 1.98^{c}$ & $500 \mathrm{mg} \mathrm{L}^{-1}$ & $\mathrm{NHB}$ \\
\hline $\begin{array}{l}\text { Total suspended } \\
\text { solids }\left(\mathrm{mg} \mathrm{L}^{-1}\right)\end{array}$ & $1000 \pm 1.03^{a}$ & $2500 \pm 0.99^{b}$ & $2000 \pm 2.04^{b}$ & NAD & 50.00 \\
\hline $\begin{array}{l}\text { Total dissolved solid } \\
\left(\mathrm{mg} \mathrm{L}^{-1}\right)\end{array}$ & $2500 \pm 0.35^{c}$ & $4000 \pm 0.44^{b}$ & $5800 \pm 0.53^{a}$ & NAD & 250.00 \\
\hline $\begin{array}{l}\text { Total hardness } \\
\left(\mathrm{mg} \mathrm{L}^{-1}\right)\end{array}$ & $55.00 \pm 0.77^{a}$ & $80.00 \pm 0.32^{b}$ & $95.50 \pm 0.35^{c}$ & 150 & 500.00 \\
\hline Chloride (mg L-1) & $85 \pm 0.19^{b}$ & $72 \pm 0.08^{a}$ & $78 \pm 0.10^{c}$ & 250 & 250.00 \\
\hline $\begin{array}{l}\text { Dissolved oxygen } \\
\left(\mathrm{mg} \mathrm{L}^{-1}\right)\end{array}$ & $3.13 \pm 0.61^{a}$ & $3.18 \pm 0.65^{\mathrm{a}}$ & $2.05 \pm 0.59^{a}$ & NAD & 10.00 \\
\hline $\begin{array}{l}\text { Biochemical oxygen } \\
\text { demand }\left(\mathrm{mg} \mathrm{L}^{-1}\right)\end{array}$ & $5.55 \pm 0.66^{b}$ & $6.00 \pm 0.60^{\mathrm{b}}$ & $5.58 \pm 0.47^{b}$ & NAD & 10.00 \\
\hline Sulphate $\left(\mathrm{mg} \mathrm{L}^{-1}\right)$ & $15.76 \pm 3.33^{a}$ & $15.94 \pm 1.01^{\mathrm{c}}$ & $16.23 \pm 2.09^{b}$ & 100 & $\mathrm{NHB}$ \\
\hline Phosphate $\left(\mathrm{mg} \mathrm{L}^{-1}\right)$ & $49.55 \pm 0.97^{a}$ & $48.10 \pm 2.55^{b}$ & $47.45 \pm 1.03^{b}$ & NAD & 5.00 \\
\hline Nitrate $\left(\mathrm{mg} \mathrm{L}^{-1}\right)$ & $0.81 \pm 0.13^{\mathrm{a}}$ & $0.99 \pm 0.06^{b}$ & $0.89 \pm 0.11^{\mathrm{b}}$ & 50.00 & 50.00 \\
\hline
\end{tabular}

The results are means and standard deviations of triplicate determinations. Values with similar alphabets along the same row are not statistically significant at $p<0.05$. Values with different alphabets along the same row are statistically significant at $p<0.05$.

*NSDWQ (MPL): Nigerian Standard for Drinking Water Quality; MPL: Maximum Permissible Limits; WHO: World Health Organization; $\mathrm{NAD}=$ No Available Data; $\mathrm{NHB}=$ No Health Baseline. 


\section{Non-carcinogenic health risks}

In non-carcinogenic risk assessment, the first step is to calculate the chronic daily intake. As shown in Table V, the mean CDI of potentially toxic elements for children and adults through ingestion of contaminated water was reported in the order: upstream>downstream>midstream. As shown in Figure 2, the studied potentially toxic elements recorded hazard quotient values less than 1 for children and adults. Based on the health risk investigation of $\mathrm{As}, \mathrm{Cd}, \mathrm{Cr}, \mathrm{Ni}, \mathrm{Pb}, \mathrm{Zn}$, and $\mathrm{Cu}$, the mean hazard quotients generally suggests an acceptable level of non-carcinogenic health risk in the water samples collected from Njaba River. After calculation of the individual hazard quotients for children and adults, it can be deduced that the contribution of the potentially toxic elements to the non-carcinogenic health risk for adults was in the order: $\mathrm{As}>\mathrm{Pb}>\mathrm{Cd}>\mathrm{Cr}>\mathrm{Cu}>\mathrm{Ni}>\mathrm{Zn}$, while the contribution of the potentially toxic elements to the noncarcinogenic health risk for children was in the order: $\mathrm{Zn}>\mathrm{Cd}>\mathrm{As}>\mathrm{Ni}>\mathrm{Cr}>\mathrm{Cu}>\mathrm{Pb}$. [24,25,38] stated that when $\mathrm{HQ}$ and $\mathrm{HI}$ values are less than 1, there is no obvious risk to the residents' health, but if the value exceeds one, there may be a concern for possible non-carcinogenic effects. The non-carcinogenic human health risk of potentially toxic elements for children and adults in Njaba River is presented in Figure 2.

Table V. Chronic daily intake of potentially toxic elements for children and adults in Njaba River

\begin{tabular}{l|ccc|ccc}
\hline \multirow{2}{*}{$\begin{array}{l}\text { Potentially toxic } \\
\text { elements }\end{array}$} & \multicolumn{3}{c|}{ CDI $_{\text {ingestion Adults }}$} & \multicolumn{3}{c}{ CDI $_{\text {ingestion }}$ Children } \\
\cline { 2 - 7 } & Upstream & Midstream & Downstream & Upstream & Midstream & Downstream \\
\hline As & $4.71 \mathrm{E}-07$ & $5.97 \mathrm{E}-07$ & $6.60 \mathrm{E}-07$ & $1.10 \mathrm{E}-06$ & $1.39 \mathrm{E}-06$ & $1.54 \mathrm{E}-06$ \\
$\mathrm{Cd}$ & $5.66 \mathrm{E}-07$ & $1.89 \mathrm{E}-07$ & $3.77 \mathrm{E}-07$ & $1.32 \mathrm{E}-06$ & $4.40 \mathrm{E}-07$ & $8.80 \mathrm{E}-07$ \\
$\mathrm{Cr}$ & $2.33 \mathrm{E}-06$ & $8.49 \mathrm{E}-07$ & $1.57 \mathrm{E}-06$ & $5.43 \mathrm{E}-06$ & $1.98 \mathrm{E}-06$ & $3.67 \mathrm{E}-06$ \\
$\mathrm{Ni}$ & $1.67 \mathrm{E}-06$ & $9.74 \mathrm{E}-07$ & $1.38 \mathrm{E}-06$ & $3.89 \mathrm{E}-06$ & $2.27 \mathrm{E}-06$ & $3.23 \mathrm{E}-06$ \\
$\mathrm{~Pb}$ & $2.67 \mathrm{E}-06$ & $1.57 \mathrm{E}-06$ & $2.89 \mathrm{E}-06$ & $6.23 \mathrm{E}-06$ & $3.67 \mathrm{E}-06$ & $6.75 \mathrm{E}-06$ \\
$\mathrm{Zn}$ & $3.05 \mathrm{E}-06$ & $1.92 \mathrm{E}-06$ & $2.42 \mathrm{E}-06$ & $7.11 \mathrm{E}-06$ & $4.47 \mathrm{E}-06$ & $5.65 \mathrm{E}-06$ \\
$\mathrm{Cu}$ & $1.04 \mathrm{E}-06$ & $5.03 \mathrm{E}-07$ & $7.86 \mathrm{E}-07$ & $2.42 \mathrm{E}-06$ & $1.17 \mathrm{E}-06$ & $1.83 \mathrm{E}-06$ \\
$\mathrm{Mean} \mathrm{CDI}$ & $1.18 \mathrm{E}-05$ & $6.60 \mathrm{E}-06$ & $1.01 \mathrm{E}-05$ & $2.75 \mathrm{E}-05$ & $1.54 \mathrm{E}-05$ & $2.36 \mathrm{E}-05$ \\
\hline
\end{tabular}




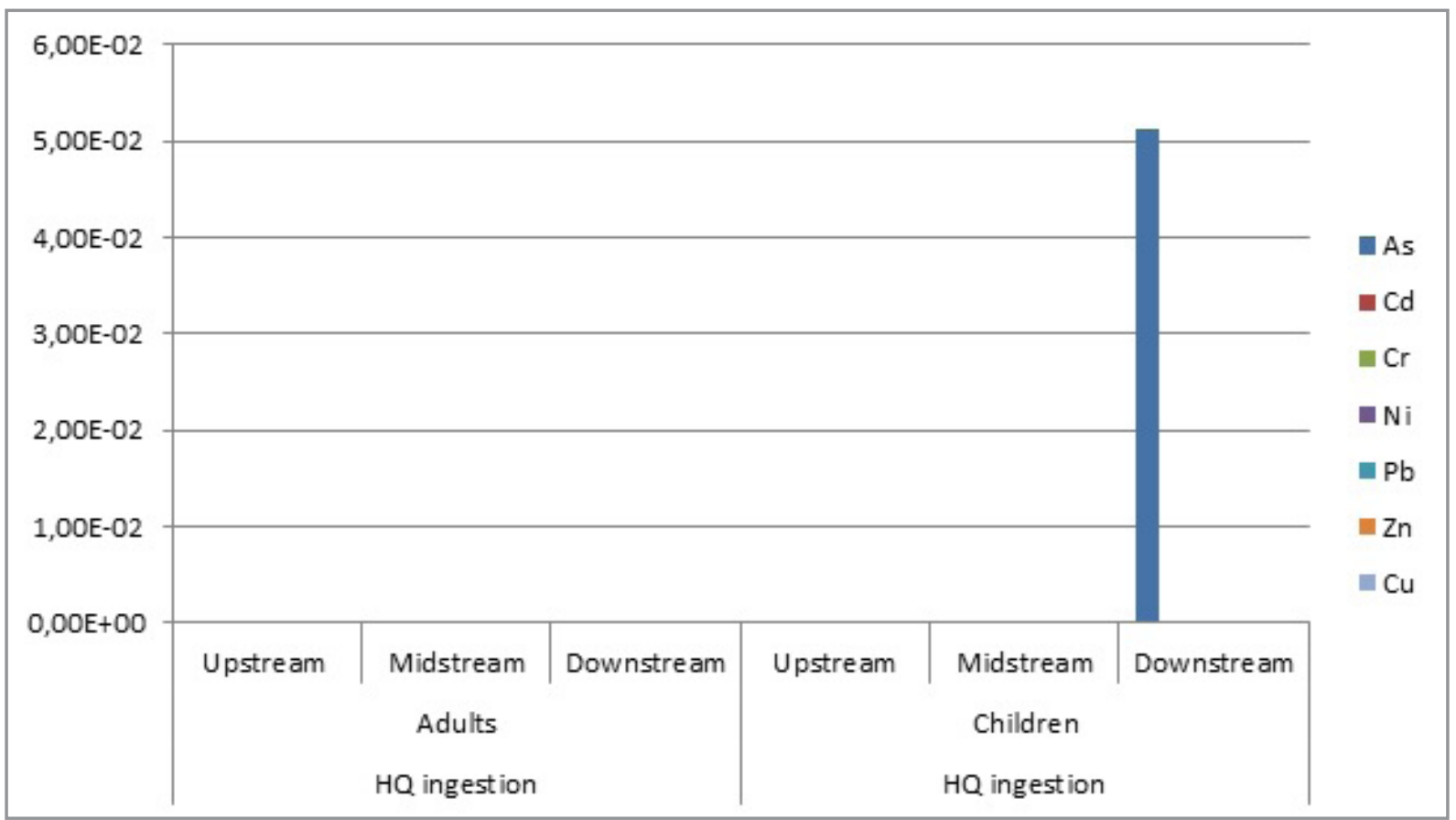

Figure 2. Non-carcinogenic human health risk of potentially toxic elements for children and adults in Njaba River.

\section{Carcinogenic health risks}

Potentially toxic elements such as $\mathrm{As}, \mathrm{Cd}, \mathrm{Cr}(\mathrm{VI}), \mathrm{Ni}$, and $\mathrm{Pb}$ can magnify the risk of cancer in humans $[18,19,22,38]$. Long term exposure to dangerous metals could result in numerous kinds of cancer [18]. In this research, $\mathrm{As}, \mathrm{Cd}, \mathrm{Cr}(\mathrm{VI}), \mathrm{Ni}$, and $\mathrm{Pb}$ were investigated as the carcinogens; the total exposure of the population was ascertained using the mean CDI values reported in Table V. Cancer risks of potentially toxic elements in Njaba River is presented in Figure 3, while the cancer slope factor (CSF) values for individual metals are recorded in Table II. According to USEPA [22] and Yang et al. [40], ILCR values less than $1 \times 10^{-6}$ are considered unimportant and can be disregarded, while an ILCR value exceeding $1 \times 10^{-4}$ is considered detrimental.

As shown in Figure 3, the total cancer risks reported for adults are generally within the acceptable limit while the total cancer risk $\left(\mathrm{CR}_{\mathrm{t}}\right)$ reported for children are above the acceptable limit of potentially toxic elements in the water. Similar results were reported by $[7,16,19]$ in drinking water in Zahedan city and Khorramabad, Iran, and drinking water from shallow groundwater wells in an agricultural area in Ubon Ratchathani province, Thailand, respectively. $[7,16,39,42]$ noted that CR values less than $1 \times 10^{-6}$ are considered unimportant and can be disregarded, while CR values exceeding $1 \times 10^{-4}$ is considered detrimental to health. The carcinogenic risk for children and adults in individual potentially toxic elements are in the order: $\mathrm{Cr}>\mathrm{Pb}>\mathrm{Cd}>\mathrm{Ni}>\mathrm{As}$. The findings from this research generally indicate that cancer risks from the studied potentially toxic elements in Njaba River are higher in children than in adults. 


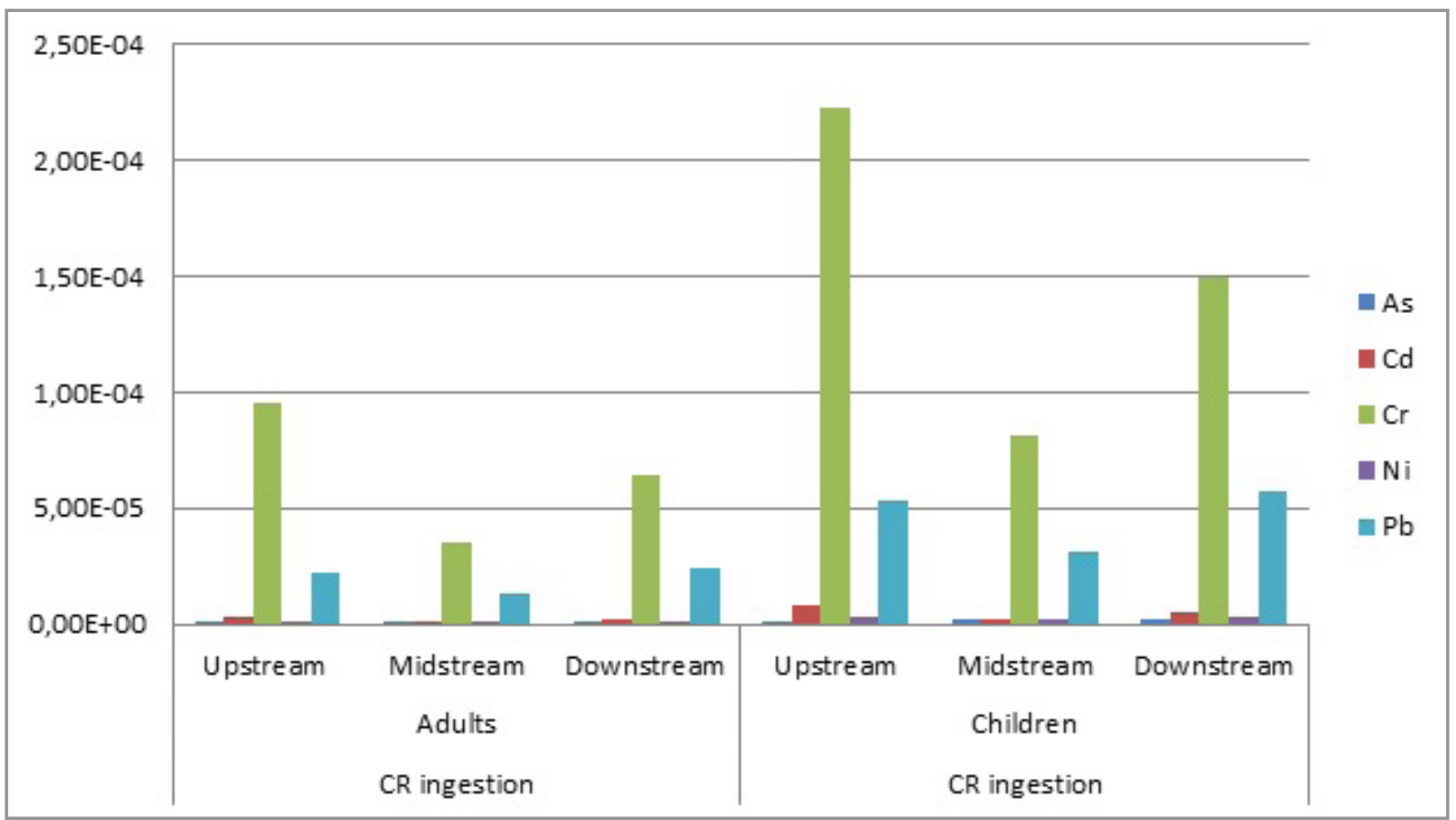

Figure 3. Cancer risks of potentially toxic elements in Njaba River.

\section{CONCLUSION}

This research has revealed that Njaba River is acidic (low pH), with a high electrical conductivity, total suspended and dissolved solid, phosphate, and total solid. The high values reported are a clear indication of the influence of human activities within and around the river. It is noteworthy to mention that consumption of water with high total solid, total dissolved and total suspended solid is detrimental to human health. The local populations who consume water from Njaba River are hereby advised to purify the water before usage. This research also investigated the health risk due to potentially toxic elements exposure in the river. Carcinogenic and non-carcinogenic health risks for children and adults were estimated. Mean CDI of potentially toxic elements in $\mathrm{mg} \mathrm{L}^{-1} /$ day for children and adults through oral intake of contaminated water was reported in the order: upstream > downstream $>$ midstream. Based on the health risk estimation of the potentially toxic elements ( $\mathrm{As}, \mathrm{Cd}, \mathrm{Cr}, \mathrm{Ni}, \mathrm{Pb}, \mathrm{Zn}$, and $\mathrm{Cu}$ ), the mean hazard quotients generally suggests an acceptable degree of non-carcinogenic health impact on children and adults. Similarly, the total chronic hazard index (THI) which is the addition of the individual potentially toxic element hazard quotients for children and adults recorded a value less than 1. This implies that there is generally no obvious risk to children and adults health. Furthermore, the total cancer risk reported was within the acceptable limit for adults and above the acceptable limit for children. This research has provided the necessary information that can help the decision-makers to establish comprehensive regulations and policies to protect the health of the local population especially the children within and around the study area.

\section{Authors' contribution}

All the authors contributed equally to the preparation of this manuscript. All authors read and approved the final manuscript.

\section{Conflict of Interest}

The authors of this research declare that they have no conflict of interest. 


\section{REFERENCES}

1. Saleh, H. N.; Panahande, M.; Yousefi M. Biol. Trace Elem. Res., 2019, 190 (1), pp 251-261 (https:// doi.org/10.1007/s12011-018-1516-6).

2. Pazand, K.; Khosravi, D.; Ghaderi, M. R.; Rezvanianzadeh, R. Journal of Water \& Health, 2018, 16 (4), pp 622-634 (https://doi.org/10.2166/wh.2018.034).

3. Kumar, M.; Ramanathan, A. L.; Tripathi, R.; Farswan, S.; Kumar, D.; Bhattacharya, P. Chemosphere, 2017, 166, pp 135-145 (https://doi.org/10.1016/j.chemosphere.2016.09.086).

4. Barzegar, R.; Asghari, M.; Soltani, E. F.; Tziritis, E.; Kazemian, N. Exposure and Health, 2017, pp 1-15 (https://doi.org/10.1007/s12403-017-0267-5).

5. Li, F.; Qiu, Z.; Zhang, J.; Liu, W.; Liu, C.; Zeng, G. Int. J. Environ. Res. Public Health, 2017, 14, 768 (https://doi.org/10.3390/ijerph14070768).

6. Lu, S. Y.; Zhang, H. M.; Sojinu, S. O.; Liu, G. H.; Zhang, J. Q.; Ni, H. G. Environ. Monit. Assess., 2015, 187 (1), article 4220 (https://doi.org/10.1007/s10661-014-4220-9).

7. Mohadeseh, D.; Hossein, K.; Seyed, D. A.; Ayat, H. P.; Amir, H. M.; Davoud, B.; Mohammad, H.; Hossein, A.; Edris, B.; Fatemeh, P. J. Environ. Health Sci. Eng., 2019, 17, pp 1163-1169 (https://doi. org/10.1007/s40201-019-00430-6).

8. Akubugwo, E. I.; Nwachukwu, M. I.; Odika, P. C.; Duru, M. K. IOSR J. Environ. Sci., Toxicol. Food Technol., 2013, 4 (6), pp 33-37 (https://doi.org/10.9790/2402-0463337).

9. Xiao, R.; Wang, S.; Li, R.; Wang, J. J.; Zhang, Z. Ecotoxicol. Environ. Saf., 2017, 141, pp 17-24 (https://doi.org/10.1016/j.ecoenv.2017.03.002).

10. Verla, E. N.; Verla, A. W.; Enyoh, C. E. Chem. Afr., 2020, 3, pp 427-438 (https://doi.org/10.1007/ s42250-020-00124-9).

11. Ahiarakwem, C. A.; Onyekuru, S. O. J. Water Resour. Prot., 2011, 3 (9), pp 686-693 (https://doi. org/10.4236/jwarp.2011.39079).

12. Joseph, A.; Majesty, D.; Friday, U. J. Ecobiotechnol., 2019, 11, pp 1-5 (https://doi.org/10.25081/ jebt.2019.v11.3866).

13. American Public Health, Association (APHA), American Water Works Association (AWWA), and Water Pollution Control Federation (WPCF), 1998.

14. Standard Methods for the Examination of Water and Wastewater 19th Edition, American Public Health Association (APHA). Washington. DC, 2005.

15. Enyoh, C. E.; Isiuku, B. O. Chem. Afr., 2020, 3, pp 1059-1071 (https://doi.org/10.1007/s42250-02000171-2).

16. Mohammadi, A. A.; Zareib, A.; Majidic, S.; Ghaderpouryd, A.; Hashempoure, Y.; Saghif, M. H.; Mahmood, A. A.; Hosseingholizadehi, N.; Ghaderpoori, M. MethodsX, 2019, 6 (1), pp 1642-1651 (https://doi.org/10.1016/j.mex.2019.07.017).

17. Bempah, C. K.; Ewusi, A. Environ. Monit. Assess., 2016, 188, article nº 261 (https://doi.org/10.1007/ s10661-016-5241-3).

18. Eze, V. C.; Onwukeme, V. I.; Enyoh, C. E. Int. J. Environ. Anal. Chem., 2020 (https://doi.org/10.1080/ 03067319.2020.1772778).

19. Wongsasuluk, P.; Chotpantarat, S.; Siriwong, W.; Robson, M. Environ. Geochem. Health, 2014, 36, pp 169-182 (https://doi.org/10.1007/s10653-013-9537-8).

20. Wu, B.; Zhao, D.; Jia, H.; Zhang, Y.; Zhang, X.; Cheng, S. Bull Environ. Contam. Toxicol., 2009, 82, pp 405-409 (https://doi.org/10.1007/s00128-008-9497-3).

21. U.S. Environmental Protection Agency. Risk Assessment Guidance for Superfund, Volume 1, Human Health Evaluation Manual (Part A). USEPA Office of Emergency and Remedial Response. Washington (DC), 2010.

22. Huang, M.; Zhou, S.; Sun, B.; Zhao, Q. Sci. Total Environ, 2008, 405 (1-3), pp 54-61 (https://doi. org/10.1016/j.scitotenv.2008.07.004). 
23. Bamuwamye, M.; Ogwok, P.; Tumuhairwe, V. J. Environ. Pollut. Hum. Health, 2015, 3 (2), pp 24-30. Available at: http://pubs.sciepub.com/jephh/3/2/1/ [Accessed 10 March 2020].

24. Kamunda, C.; Mathuthu, M.; Madhuku, M. Int. J. Environ. Res. Public Health, 2016, 13 (7), 663 (https:// doi.org/10.3390/ijerph13070663).

25. Guerra, F.; Trevizam, A. R.; Muraoka, T.; Marcante, N. C.; Canniatti-Brazaca, S. G. Sci. Agric., 2012, 69 (1), pp 54-60 (https://doi.org/10.1590/S0103-90162012000100008).

26. Sultana, M. S.; Rana, S.; Yamazaki, S.; Aono, T.; Yoshida, S. Cogent Environ. Sci., 2017, 3 (1) (https:// doi.org/10.1080/23311843.2017.1291107).

27. Tepanosyan, G.; Maghakyan, N.; Sahakyan, L.; Saghatelyan, A. Ecotoxicol. Environ. Saf., 2017, 142, pp 257-265 (https://doi.org/10.1016/j.ecoenv.2017.04.013).

28. World Health Organization, WHO. Environmental Health Criteria 27, Guidelines on studies on Environmental Epidemiology. Joint Sponsorship UNEP/ILO/WHO. Geneva, 2003.

29. Choudhary, S.; Ramteke, S.; Rajhans, K.; Sahu, P.; Chakradhari, S.; Patel, K.; Matini, L. J. Water Resour. Prot., 2016, 8, pp 12-19 (https://doi.org/10.4236/jwarp.2016.81002).

30. Adamu, G. A.; Sallau, M. S.; Idris, S. O.; Agbaji, E. B. Study of pollution level for drinking water quality assessment of Kafin-Chiri reservoir, Kano State, Nigeria. Proceedings of the $36^{\text {th }}$ Annual International Conference of Chemical Society of Nigeria, Minna, Niger State, Nigeria, 2013, pp 274-280.

31. Fallahzadeh, R. A.; Ghaneian, M. T.; Miri, M.; Dashti, M. M. Environ. Sci. Pollut. Res., 2017, 24, pp 24790-24802 (https://doi.org/10.1007/s11356-017-0102-3).

32. Woke, G. N.; Babatunde, B. B.; Aleleye, W. Global J. Environ. Sci., 2013, 12 (1), pp $41-47$ (https://doi. org/10.4314/gjes.v12i1.5).

33. Loucks, D. P.; van Beek, E. Water Resources Planning and Management: An Overview. In: Water Resource Systems Planning and Management, Springer, Cham, 2017 (https://doi.org/10.1007/9783-319-44234-1_1).

34. Gray, N. F. Drinking Water Quality Problems and Solutions. John Wiley and Sons, London, UK, 1994, pp 43-63.

35. Garg, R. K.; Rao, R. J.; Uchchariya, D. U.; Shukla, G.; Saksen, D. N. Afri. J. Environ. Sci. Technol, 2010, 4 (2), pp 61-76. Available at: https://www.ajol.info/index.php/ajest/article/view/56323 [Accessed 10 March 2020].

36. Obire, O.; Tamuno, D. C.; Womedo, S. A. J. Appl. Sci. Environ. Mgt., 2003, 7 (1), pp 43 - 49 (https:// doi.org/10.4314/jasem.v7i1.17164).

37. Beka, N. C.; Aga, T.; Eziashi, A. C. The Pacific Journal of Science and Technology, 2009, 10 (2), pp 626-632. Available at: http://www.akamaiuniversity.us/PJST10_2_626.pdf [Accessed 10 March 2020].

38. Enyoh, C. E.; Isiuku, B. O. Int. J. Environ. Anal. Chem., 2020 (https://doi.org/10.1080/03067319.2020.1 773455).

39. Zhu, Q.; Wu, J.; Wang, L.; Yang, G.; Zhang, X. Water, Air, Soil Pollut., 2015, 226, article n $^{\circ} 429$ (https:// doi.org/10.1007/s11270-015-2680-3).

40. Alidadi, H.; Sany, S. B. T.; Oftadeh, B. Z. G.; Mohamad, T.; Shamszade, H.; Fakhari, M. Environ. Health Prev. Med., 2019, 24, article no 59 (https://doi.org/10.1186/s12199-019-0812-x).

41. Abdullah, E. J. Journal of Natural Sciences Research, 2013, 3 (8), pp 63-64 (https://core.ac.uk/ download/pdf/234654183.pdf).

42. Eze, V. C.; Enyoh, C. E.; Ndife, C. T. Chem. Afr., 2020, 4, pp 127-136 (https://doi.org/10.1007/s42250020-00194-9).

43. Isiuku, B. O.; Enyoh, C. E. Environmental Advances, 2020, 2, 100018 (https://doi.org/10.1016/j. envadv.2020.100018).

44. Enyoh, C. E.; Ohiagu, F. O.; Verla, A. W.; Verla, E. N. Int. J. Environ. Anal. Chem., 2020 (https://doi.or g/10.1080/03067319.2020.1807535).

45. Ahiarakwem, C. A.; Onyekwuru, S. O. J. Water Res. and Prot., 2011, 3 (9), pp 686-693 (https://doi. org/10.4236/jwarp.2011.39079). 
46. Wirnkor, V. A.; Ngozi, V. E.; Emeka, A. C.; Ebere, E. C. International Journal of Advanced Scientific Research, 2018, 3, pp 40-46. Available at: https://www.semanticscholar.org/paper/Water-pollutionscenario-at-river-uramurukwa-owerri-Wirnkor-Ngozi/7efe39a1164c734000544337268b37cd538bef48 [Accessed 10 March 2020]. 